\title{
Two new species of Pyemotes closely related to P. tritici (Acari: Pyemotidae) ${ }^{1}$
}

\author{
LICHEN YU ${ }^{\mathrm{a}, \mathrm{c}}$, ZHI-QIANG ZHANG ${ }^{\mathrm{b}, \mathrm{c}}$ \& LIMIN HE LI $^{\mathrm{a}}$ \\ ${ }^{a}$ Changli Fruit Tree Research Institute, Hebei Academy of Agricultural and Forestry Sciences, Changli, Hebei, China \\ ${ }^{b}$ New Zealand Arthropod Collection, Landcare Research, 231 Morrin Road, St. Johns, Auckland 1072, New Zealand \\ c Corresponding authors: ylc825@gmail.com, zhangz@landcareresearch.co.nz.
}

\begin{abstract}
Two new species of Pyemotes are described: Pyemotes zhonghuajia sp. nov. parasitic on a variety of Coleoptera, Lepidoptera and Hymenoptera in China and Pyemotes turkeyensis sp. nov. parasitic on moths in Turkey. Pyemotes tritici (LaGreze-Fossat \& Montagne, 1851) in its revised concept is redescribed based on specimens from USA and Mexico. Keys to separate both adult males and females of these species are provided. Grandjean's notation for idiosomal and leg chaetotaxy is applied to the Pyemotidae.
\end{abstract}

Key words: Mites, ectoparasites, insects, biological control agent, China, USA, Mexico, Turkey

\section{Introduction}

Mites of the family Pyemotidae are parasitoids of insects. The Pyemotes ventricosus group, at least, are of increasing interest and concern in systematic and applied acarology due to their roles in biological control of pest insects and their medical importance-being the "straw itch mites". Since Cross (1965), the classification of this family has changed considerably (mainly through discoveries of new species and new characters), and this family in its restricted sense in the most recent mite classification (Walter et al. 2009) consists of a single genus, Pyemotes Amerling, 1861.

\section{Historic review of the genus}

The early taxonomy of the genus Pyemotes was rather confusing due to the lack of detailed descriptions of the common species. Krczal (1959a) provided a comprehensive review of the genus; he described four species new to science, redescribed two common species [type species $P$. scolyti Oudemans, 1936 and $P$. herfsi (Oudemans, 1936)], and provided a literature review of 14 other species with uncertain identity, including the common species P. tritici (LaGreze-Fossat \& Montagne, 1851) and P. ventricosus (Newport, 1850), which were not re-described and not included in his key to species. He suggested that the common straw itch mite was $P$. tritici, rather than $P$. ventricosus, which might be restricted to Hymenoptera. This view was later endorsed by Moser (1975) through crossmating experiments of various populations of straw itch mites from different localities.

Krczal (1959b, 1963) described two new species, P. boylei and P. zwoelferi, respectively. However, $P$. boylei was later considered a synonym of $P$. tritici by Cross and Moser (1975), and $P$. zwoelferi was synonymized with $P$. herfsi by Cross et al. (1981).

Cross and Moser (1971) described P. parviscolyti from Louisiana, USA. Later, Cross and Moser (1975) described $P$. dimorphus from New Hampshire, USA and divided the 13 species known to them into two groups: 1) the scolyti group (P. scolyti, P. parviscolyti and P. dimorphus), being primarily associates of bark beetles, often non-

1. This research received financial supports from the National Natural Science Foundation of China (3977062), the Provincial Natural Science Foundation of Hebei (397328), and the Scholarship Council of Hebei Province. 
We also observed a pair of un-named structure (named X in Figs 40-42) flanking the aedeagus. They are slightly lateral to setae $p s_{2}$. When the capsule is positioned towards the rear end, this pair looks like a pair of suckers, with a pair of bulb-like structure extending from it (Fig. 42). In most specimens this pair is difficult to see. In the undescribed species of Pyemotes from New Zealand, it is club-shaped. Future studies using SEM will be needed to reveal this structure.
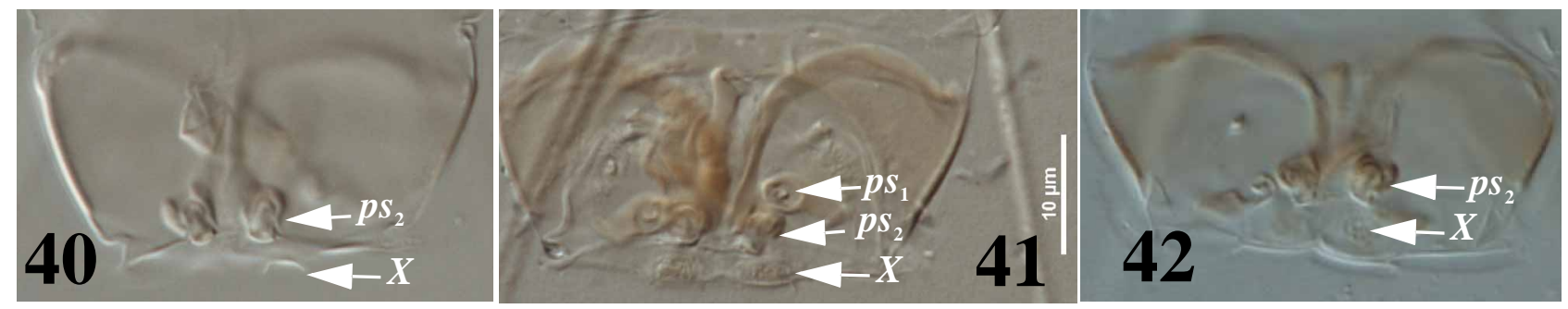

FIGURES 40-42. Photomicrographs of genital area in males, with a focus on setae $\mathrm{ps}_{2}$. 40, Pyemotes zhonghuajia sp. nov.; 41, Pyemotes tritici; 42, Pyemotes turkeyensis sp. nov.; all three figures of the same scale (scale bar 10 micrometers).

\section{Acknowledgements}

We are most grateful to Dr John Moser (USA) for the loan of specimens of Pyemotes in his collection and Dr Evert Lindquist for confirming the presence of $a g$ setae in males of his unnamed Pyemotes species. We also thank Dr Moser and Dr Qinghai Fan (New Zealand) for reviewing the manuscript and useful comments. Lichen Yu acknowledges the support of Professor Lairong Liang (Fudan University), Professor Huaiwen Yang and Academician Yuyuan Guo (Chinese Academy of Agricultural Sciences), Professor Haibo Wang (Hebei Academy of Agricultural and Forestry Sciences), and Rosa Henderson (Landcare Research, Auckland). While this paper was prepared, Zhi-Qiang Zhang was supported by the New Zealand Foundation for Research, Science and Technology through backbone funding of the "Defining New Zealand's Land Biota" programme.

\section{References}

Amerling, C. (1861) Über die Naturökonomie einiger Milben, insbesondere der Trombidiiden. Sitzungsberichte der Königlich Böhmischen Gesellschaft der Wissenschaften in Prag, pp. 54-56 (cited by Krczal 1959, not seen).

Bruce, W.A. \& LeCato, G.L. (1980) Pyemotes tritici: A potential new agent for biological control of the red imported fire ant, Solenopsis invicta (Acari: Pyemotidae). International Journal of Acarology, 6, 271-274.

Bruce, W.A., Kethley, J.B. \& Kaliszewski, M.J. (1993) Morphology of the gnathosoma of Pyemotes tritici: Cheliceral stylets and an associated cheliceral structure (Acari : Pyemotidae). International Journal of Acarology, 19, 127-136.

Chinniah, C. \& Mohanasundaram, M. (1999) Record of two parasitic mites on insects from Tamil Nadu, India. Pest Management and Economic Zoology, 7(1), 15-20.

Cobanoglu, S. \& Doganlar, M. (2006) A new Pyemotes (Acari: Pyemotidae) reared from larvae of the almond seed wasp, Eurytoma amygdali (Hymenoptera: Eurytomidae) from Hatay, Turkey. Zoology in the Middle East, 39, 101-106.

Cross, E.A. (1965) The generic relationships of the family Pyemotidae (Acarina : Trombidiformes). University of Kansas Science Bulletin, 45, 29-275.

Cross, E.A. \& Moser, J.C. (1971) Taxonomy and biology of some Pyemotidae (Acarina: Tarsonemoidea) inhabiting bark beetle galleries in North American conifers. Acarologia, 13(1), 47-64.

Cross, E.A. \& Moser, J.C. (1975) A new, dimorphic species of Pyemotes and a key to previously described forms (Acarina: Tarsonemoidea). Annals of Entomological Society of America, 68, 723-732.

Cross, E.A., Moser, J.C. \& Rack, G. (1981) Some new forms of Pyemotes (Acarina : Pyemotidae) from forest insects, with remarks on polymorphism. International Journal of Acarology, 7, 179-196.

Han, J.-C., He L.-M., Jiao, R., Hao, B.-F., Xu, C.-X., \&, Yu, L.-C. (2008) Analysis of the toxin gene ana logs cloned from Pyemotes phloeosinus sp. nov. Journal of Hebei Agricultural Sciences, 12(1), $72-74$ (in Chinese with English abstract).

Khaustov, A.A. (1998) A new species of Pyemotes (Acari: Heterostigmata: Pyemotidae) associated with bark beetles (Coleoptera: Scolytidae) from Crimea. Acarina, 6, 37-39. 
Khaustov, A.A. (1999) A new species of Pyemotes (Acari: Heterostigmata: Pyemotidae) associated with bark beetles (Coleoptera: Scolytidae) from Crimea. Acarina, 6(1-2), 37-39.

Khaustov, A.A. (2004) New replacement names for Pyemotes moseri Khaustov, 1998 and Archidispus kurosai Khaustov, 2004 (Acari: Heterostigmata: Pyemotidae: Scutacaridae). Acarina, 12(1), 47.

Krczal, H. (1959a) Systematik und Ökologie der Pyemotiden. In: Stammer, H.J. (Ed.), Beiträge zur Systematik und Ökologie Mitteleuropäischer Acarina. Akademische Verlagsgesselschaft, Leipzig. Volume 1, Part 2, pp. 1-625.

Krczal, H. (1959b) Pyemotes boylei, eine neue Pyemotid aus Hawaii. Zoologischer Anzeiger, 163, 148-152.

Krczal, H. (1963) Pyemotes zwoelferi, eine neue Insekten-Parasitische Pyemotes aus der Schweiz. Zoologischer Anzeiger, 170, $336-342$.

LaGreze-Fossat, A. \& Montagne, R.-J. (1851) Observations microscopiques sur la mite du blé. Recueil agronomique (Mautauban), 32(2), 37-66.

Lindquist, E.E. (1986) The world genera of Tarsonemidae (Acari: Heterostigmata): a morphological, phylogenetic, and systematic revision, with a reclassification of family-group taxa in the Heterostigmata. Memoirs of the Entomological Society of Canada, (136), 1-517.

Mahunka, S. \& Mahunka-Papp, L. (1998) Pyemotes muraiae sp.n. (Acari: Heterostigmata: Pyemotidae) parazitsing a Hymenoptera larva. Parasitologica Hungarica, 31, 47-51.

Moser, J.C. (1975) Biosystematics of the straw itch mite with special reference to nomenclature and dermatology. Transactions of the Royal Entomological Society, London, 127, 185-191.

Moser, J.C., Smiley, RL. \& Otvos, L.S. (1975) A new Pyemotes (Acari: Pyemotidae) resred from the Dauglas-fir cone moth. International Journal of Acarology, 13(2), 141-147.

Newport, G. (1850) Further observations on the habits of Monodontomerus, with some account of a new Acarus, Heteropus ventricosus, a parasite in the nests of Anthophora retusa. Annals and Magazine of Natural History Series 2. 6, 395-396.

Oudemans, A.C. (1936) Neues über Pediculoides Targ.-Tozz. 1878. Festschrift für Embrik Strand, 1, 391-404.

Tomalski, M., Bruce, W.A., Travis, J. \& Blum, M.S. (1988) Preliminary characterization of toxins from the straw itch mite Pyemotes tritici, which induces paralysis in the larvae of a moth. Toxicon, 26, 127-132.

Tomalski, M.D., Kutney, R., Bruce, W.A., Brown, M.S. \& Travis, J. (1989) Purification and characterization of insect toxins derived from the mite Pyemotes tritici. Toxicon, 27, 1151-1167.

Walter, D.E., Lindquist, E.E., Smith, I.M., Cook, D.R. \& Krantz, G.W. (2009) Chapter thirteen Order Trombidiformes. In: Krantz, G.W. \& Walter, D.E. (eds) A Manual of Acarology Third edition. Texas Tech University Press, Lubbock, pp. 233420.

Yu, L.-C. \& Liang, L.-R. (1996) A new species of Pyemotes (Acari: Pyemotidae) parasitic on bark beetles (Coleoptera: Scolytidae) from Hebei, China. Systematic and Applied Acarology, 1, 167-171.

Zhang, Z.-S., Xiong, D.-P. \& Cheng, W. (2008) Control of stem borers by a parasitoid, Pyemotes trittci Lagreze-Fossot \& Montane. Chinese Journal of Biological Control, 24(1), 1-6. [notes: trittci is a print error and should be tritici]. 